\title{
Mechanisms Regulating Grain Contamination with Trichothecenes Translocated from the Stem Base of Wheat (Triticum aestivum) Infected with Fusarium culmorum
}

\author{
Mark Winter, Birger Koopmann, Katharina Döll, Petr Karlovsky, \\ Ute Kropf, Klaus Schlüter, and Andreas von Tiedemann
}

First, second, and fifth authors: Plant Pathology and Crop Protection Division, Department of Crop Sciences, Faculty of Agriculture, GeorgAugust University Göttingen, Grisebachstraße 6, D-37077 Göttingen, Germany; third and fourth authors: Molecular Phytopathology and Mycotoxin Research Division, Department of Crop Sciences, Faculty of Agriculture, Georg-August University Göttingen, Grisebachstraße 6, D-37077 Göttingen, Germany; and fifth and sixth authors: University of Applied Sciences Kiel, Fachbereich Agrarwirtschaft (Department of Agriculture), Am Kamp 11, D-24783 Osterrönfeld, Germany.

Accepted for publication 6 February 2013.

\begin{abstract}
Winter, M., Koopmann, B., Döll, K., Karlovsky, P., Kropf, U., Schlüter, K., and von Tiedemann, A. 2013. Mechanisms regulating grain contamination with trichothecenes translocated from the stem base of wheat (Triticum aestivum) infected with Fusarium culmorum. Phytopathology 103:682-689.

Factors limiting trichothecene contamination of mature wheat grains after Fusarium infection are of major interest in crop production. In addition to ear infection, systemic translocation of deoxynivalenol (DON) may contribute to mycotoxin levels in grains after stem base infection with toxigenic Fusarium spp. However, the exact and potential mechanisms regulating DON translocation into wheat grains from the plant base are still unknown. We analyzed two wheat cultivars differing in susceptibility to Fusarium head blight (FHB), which were infected at the stem base with Fusarium culmorum in climate chamber experiments. Fungal DNA was found only in the infected stem base tissue, whereas DON and its derivative, DON-3-glucoside (D3G), were detected in upper plant

parts. Although infected stem bases contained more than $10,000 \mu \mathrm{g} \mathrm{kg}^{-1}$ dry weight (DW) of DON and mean levels of DON after translocation in the ear and husks reached $1,900 \mu \mathrm{g} \mathrm{kg}^{-1} \mathrm{DW}$, no DON or D3G was detectable in mature grains. D3G quantification revealed that DON detoxification took mainly place in the stem basis, where $\leq 50 \%$ of DON was metabolized into D3G. Enhanced expression of a gene putatively encoding a uridine diphosphate-glycosyltransferase (GenBank accession number FG985273) was observed in the stem base after infection with $F$. culmorum. Resistance to F. culmorum stem base infection, DON glycosylation in the stem base, and mycotoxin translocation were unrelated to cultivar resistance to FHB. Histological studies demonstrated that the vascular transport of DON labeled with fluorescein as a tracer from the peduncle to the grain was interrupted by a barrier zone at the interface between grain and rachilla, formerly described as "xylem discontinuity". This is the first study to demonstrate the effective control of influx of systemically translocated fungal mycotoxins into grains at the rachillaseed interface by the xylem discontinuity tissue in wheat ears.
\end{abstract}

Fusarium head blight (FHB) has become one of the most important fungal diseases in temperate zone wheat production worldwide, with a potential to induce significant losses both in yield and quality (14). FHB is predominantly caused by the two fungal pathogens Fusarium culmorum (W. G. Sm.) Sacc. and Fusarium graminearum Schwabe (26), which are able to contaminate grains with mycotoxins, which are known to cause human and animal toxicoses. Trichothecene deoxynivalenol (DON) is the predominant mycotoxin in cereal grains infected with species of Fusarium (27). Legal thresholds for DON in harvested grain have been established by the European Union since 2006 (12). Contamination of grains with trichothecenes not only puts consumers at risk but also endangers the farmers' revenues because harvested products have to be disposed when DON contamination thresholds are violated. Therefore, there is a general interest in strategies to reduce DON contaminations in cereal grains. This puts particular emphasis on understanding of all factors which may contribute to or limit the mycotoxin contamination of grains.

Corresponding author: A. von Tiedemann; E-mail address: atiedem@gwdg.de

* The $\boldsymbol{e}$-Xtra logo stands for "electronic extra" and indicates that Figure 2 appears in color online.

http://dx.doi.org/10.1094/PHYTO-11-12-0296-R

(c) 2013 The American Phytopathological Society
The main focus of previous research has been on ear infection induced by airborne conidia and ascospores. Nonetheless, the toxigenic Fusarium sp. F. culmorum is also known to be a potent soilborne pathogen inducing Fusarium crown and foot rot (FCR) on cereals throughout the world $(9,23)$. Several earlier reports indicate that $F$. culmorum residing on infested plant residues may colonize the whole stem base by step-wise penetration through the leaf sheaths until reaching the culm (6). In mature growth stages ([GS] 77 to 87 and 95), fungal hyphae may grow within the stem pith cavity and colonize the parenchyma tissue below the first node intercellularly and intracellularly (6).

Recently, it was shown that trichothecenes were synthesized by F. culmorum during infection and colonization of the stem base tissue (3). Covarelli et al. (10) reported on the translocation of DON to upper plant parts of soft wheat following stem base infection with $F$. culmorum. The authors concluded that systemic transport of DON from the stem base to the ear is a potential additional source of contamination of grain. Our own findings from a field trial in northern Germany in 2007, where noticeable amounts of DON were detected in upper parts of wheat plants that were not colonized with the fungus, confirmed these results (unpublished data). In subsequent greenhouse experiments under controlled conditions, a systemic translocation of DON from the base to the head in stem-base-infected winter wheat with toxigenic Fusarium spp. F. culmorum and F. graminearum, respectively, was confirmed (unpublished data). 
The natural detoxification process of DON into nonphytotoxic DON-3-glucoside (D3G) in wheat, which has been demonstrated after ear infection $(4,19)$, is not described for stem base infections yet. Therefore, plant detoxification of DON after stem base infection may have an influence on the extent of DON translocation and grain contamination. In addition, it is not yet clear whether the FHB resistance of the cultivar shows a correlation to D3G formation and DON translocation during FCR.

The present study investigated the rates at which DON in wheat plants infected with $F$. culmorum at the stem base is translocated to upper parts of the plant and into the grains, and addresses ratelimiting anatomical and physiological mechanisms potentially involved in regulating translocation. To this end, both translocation and detoxification of DON into a nonphytotoxic D3G were analyzed in wheat plants infected at the stem base. In addition, the expression of a gene putatively encoding for a DON-detoxifying protein and a Fusarium infection responsive gene, respectively, was analyzed during FCR disease.

\section{MATERIALS AND METHODS}

Plant material for climate chamber experiments. The two commercial German bread winter wheat varieties 'Ritmo' and 'Toras', highly susceptible and resistant to ear infection with $\mathrm{Fu}$ sarium spp., respectively, were used in this study. Seed were surface sterilized under constant agitation in a solution of silver nitrate $(0.1 \%)$ for $10 \mathrm{~min}$ and subsequently rinsed under tap water. Seeds were then placed on double-autoclaved $\left(15 \mathrm{~min}\right.$ at $\left.121^{\circ} \mathrm{C}\right)$ moist sand in petri dishes covered with aluminum foil. Vernalization of seedlings was conducted at $5^{\circ} \mathrm{C}$ for 40 days. After vernalization, two seedlings per plastic pot were planted $(9$ by $9 \mathrm{~cm})$ and grown in the climate chamber under a day and night cycle of 16 and $8 \mathrm{~h}$ and 23 and $16^{\circ} \mathrm{C}$, respectively. Relative humidity was kept particularly low $(<55 \%)$ and was continuously recorded with a data logger (Conrad Electronic SE, Hirschau, Germany). Treatments (inoculated versus noninoculated) were separated within the same climate chamber divided into two compartments by a pane of acrylic glass. Pots from the same treatments were placed in trays and watered from the bottom only. At the stem elongation stage (GS 30 and 34), secondary shoots were removed in order to keep only the main tiller (34). Plants were fertilized once per week with a compound fertilizer $\left(2 \mathrm{~g} \mathrm{liter}^{-1}\right)$ consisting of $15 \% \mathrm{~N}, 15 \%$ $\mathrm{K}_{2} \mathrm{O}, 11 \% \mathrm{P}_{2} \mathrm{O}$, and $1 \% \mathrm{MgO}$ (Hakaphos, COMPO, Muenster, Germany).

Samples for analysis were collected at two different growth stages, at the end of milk development (GS 77) and during ripening (GS 92). At GS 77, plants were cut just above crown roots. Leaf sheaths were removed and four plant organs were dissected: stem basis ( $\approx 5 \mathrm{~cm}$ long), ear rachis, husks, and grains. The plant organs were separated by hand. Plant samples were immediately frozen in liquid nitrogen and stored at $-80^{\circ} \mathrm{C}$ prior to RNA extraction. At GS 92, the same plant parts were collected. The ears were threshed with a single ear thresher (Linca, Tel Aviv, Jerusalem, Israel), allowing the retrieval of all grains for analysis. Grains, rachis, and husks were collected and stored separately. Shoot and rachis samples were ground with a ball mill (Retsch, Haan, Germany), and grains and husks were homogenized with an ultra-centrifugal mill (Retsch). In order to obtain sufficient amounts of material for the analyses, samples from six plants were merged. Climate chamber experiments were performed in two independent repetitions.

Fungal isolates. F. culmorum isolates $\mathrm{Fc} 34, \mathrm{Fc} 35$, and $\mathrm{Fc} 36$ producing DON and zearalenone were used throughout this study. The isolates were obtained from the fungal culture collection of the Department of Crop Sciences, Plant Pathology and Plant Protection Division, University of Goettingen, and were originally isolated from FHB-infected ears collected in wheat fields in Bavaria, Southern Germany. Short-term storage was performed on straw-extract agar (SEA) in petri dishes at $4{ }^{\circ} \mathrm{C}$. For SEA, $10 \mathrm{~g}$ of milled wheat straw (4-mm sieve; Retsch) was incubated in $500 \mathrm{ml}$ of tap water for $1 \mathrm{~h}$. The extract was filtered using gauze, $7.5 \mathrm{~g}$ of agar was added, and the filtrate was autoclaved at $121^{\circ} \mathrm{C}$ for 15 min.

Inoculation. Inoculum of $F$. culmorum was produced in liquid straw extract medium. Milled wheat straw (6 g, $4 \mathrm{~mm}$-sieve; Retsch, Germany) in $200 \mathrm{ml}$ of distilled water was autoclaved twice $\left(121^{\circ} \mathrm{C}\right.$ for $\left.15 \mathrm{~min}\right)$ on consecutive days. Autoclaved straw extract medium was inoculated with agar plugs overgrown with $F$. culmorum (a mixture of three isolates grown on different plates), in 1-liter Erlenmeyer flasks. Flasks were incubated on a shaker (Infors, Bottmingen, Switzerland) at $23^{\circ} \mathrm{C}$ and $100 \mathrm{rpm}$ for 10 days. After filtration, the spore suspension was adjusted to a final spore density of $8 \times 10^{5}$ conidia/ml. Roots and coleoptiles of vernalized seedlings were dip inoculated for $30 \mathrm{~min}$ in the spore suspension. Inoculated seedlings were planted into double-autoclaved soil substrate containing sand, potting soil, and steamed compost (3:12:4).

Disease severity at the stem base was assessed using a 0 to 3 scale, where $0=$ no lesion visible, $1=$ lesion covering $50 \%$ of stem surface area, $2=$ lesion covering 51 to $100 \%$ of stem surface area, and $3=$ stem base completely rotten. Plants were scored in the late milk development stage (GS 77) for typical brown, longitudinal lesions caused by Fusarium spp. on the stem base in wheat (11,37). To confirm ear infections, ears were examined for typical FHB symptoms (bleaching of spikelet) in GS 77. Ears were thoroughly observed for the occurrence of FHB symptoms in GS 77 but no bleaching of glumes or whole spikelet was detectable. The ears emerged healthy and produced fully developed grains.

Fluorescence microscopy. Wheat heads of Toras were cut $0.5 \mathrm{~cm}$ below the first spikelet. Heads were placed in a $200-\mu \mathrm{l}$ polymerase chain reaction (PCR) tube containing $100 \mu \mathrm{l}$ of DONfluorescein conjugate $(65 \mu \mathrm{l} / \mathrm{ml})$ (aokin AG, Berlin) until all DONfluorescein was taken up by the head sample. After capillary uptake, the rachis-seed interface was examined for DON-fluorescein dispersal on semithin longitudinal sections by fluorescence microscopy (DM 500 CS; Leica, Solms, Germany). Pictures were recorded by a white light camera (DFC 420, Leica, Solms, Germany) with the software IM500 (Leica). Free-hand sections of fresh material were cut with conventional razor blades. Untreated heads of Toras served as controls.

Analysis of DON and D3G content. DON and D3G were analyzed in stem base, ear rachis, husk, and grain samples. Plant tissue was milled to fine powder and, for extraction of toxins, $300,200,500$, and 1,000 mg of tissue (fresh weight), respectively, were taken. The samples were processed and analyzed by highperformance liquid chromatography tandem mass spectrometry, as described by Adejumo et al. (1), using a polar modified RP-18column (Polaris C18 Ether; Varian, Darmstadt, Germany) kept at $40^{\circ} \mathrm{C}$. A gradient of methanol in water with $7 \mathrm{mM}$ acetic acid was used as mobile phase.

Detection was performed on a triple quadrupole $1200 \mathrm{MS}$ (Varian) after electrospray ionization in a negative mode with the following mass transitions: $355>295$ and $355>265$ for DON, and $457>427$ and $457>247$ for D3G.

Matrix-matched calibration curves were prepared at 0.05 to $5 \mathrm{mg} \mathrm{kg}^{-1}$ for stem base, ear rachis, and husk; and, for wheat kernel, at 0.5 to $100 \mathrm{mg} \mathrm{kg}^{-1}$. The estimated limits of quantification based on the signal-to-noise ratio of 10:1 for DON and D3G were 50 and $200 \mu \mathrm{g} \mathrm{kg}^{-1}$ in wheat grains, $200 \mu \mathrm{g} \mathrm{kg}^{-1}$ and $1 \mathrm{mg} \mathrm{kg}^{-1}$ in husks, $250 \mu \mathrm{g} \mathrm{kg}^{-1}$ and $1 \mathrm{mg} \mathrm{kg}^{-1}$ in the rachis, and $50 \mu \mathrm{g} \mathrm{kg}^{-1}$ and $1 \mathrm{mg} \mathrm{kg}^{-1}$ in stem tissue.

RNA extraction. Stem base, rachis, filling grain, and husk samples were frozen in liquid nitrogen and ground to fine powder with mortar and pestle. Extraction was done according to the protocol of Venkatesh et al. (35), with the following modifica- 
tions: hot guanidine thiocyanate buffer $\left(80^{\circ} \mathrm{C}\right)$ was used and RNA was precipitated with lithium chloride (final concentration of $2.5 \mathrm{M}$ ). After washing of the pellet with ethanol, RNA was dissolved in RNAse-free distilled water. Quality of extracted RNA was checked by classical gel electrophoresis. RNA was stored at $-80^{\circ} \mathrm{C}$ until cDNA synthesis.

cDNA synthesis. Total RNA was reverse transcribed using the QuantiTect Reverse Transcription Kit (Qiagen, Hilden, Germany). Contaminating DNA was eliminated by the "wipeout" buffer included in the QuantiTect Reverse Transcription Kit. Success of DNA removal was checked after amplification of cDNA with quantitative (q)PCR for gene expression analysis in classical gel electrophoresis with the intron overlaying housekeeping gene actin.

Gene expression analysis. For transcript accumulation studies after stem base infection, one of the genes encoding for cytochrome P450 (CYP450) (accession number FG985275) and uridine diphosphate-glycosyltransferase (UGT) (accession number FG985273) were used. Both genes were reported to be induced after spikelet treatment with DON (36) whereas, in this study, CYP450 served as a general marker for plant stress responses because it is not involved in DON glycosylation. A similar gene from barley has been proven to be involved in glycosylation of DON in barley (32). The homologue to this gene was amplified by using the primers described by Walter et al. (36). Synthesized cDNA was diluted fivefold and $2 \mu \mathrm{l}$ of cDNA was amplified with gene-specific forward and reverse primers $(1 \mu \mathrm{M}$ each) in a total volume of $25 \mu \mathrm{l}$, containing $12.5 \mu \mathrm{l}$ of Premix Absolute Blue qPCR SYBR green fluorescein with $3 \mathrm{mM} \mathrm{MgCl}_{2}$ (Thermo Fisher Scientific, Epsom, UK). The obtained threshold cycles were calibrated against actin as housekeeping gene, known to be constitutively expressed in barley (Hordeum vulgare) (15). Real-time qPCR was performed separately for the target genes (triplicate) and housekeeping gene (duplicate). Real-time conditions were as described by Walter et al. (36). For amplification and melting curve analysis, the iCycler System (Bio-Rad, Hercules, CA) was used. Fold change values in transcript accumulation between inoculated and noninoculated samples were calculated with the formula $2^{-(\Delta \mathrm{CT} \text { target transcript sample }-\Delta \mathrm{CT} \text { target transcript control) }}(22)$.

Quantification of fungal biomass. To verify the hypothesis of systemic translocation of DON, all analyzed plant organs were analyzed for presence of DNA of F. culmorum in GS 92. DNA was extracted from ground fine powder of senescent and dry plant tissue with a cetyltrimethylammonium bromide-based method (5). DNA concentration was determined in a densitometrical assay after agarose gel electrophoresis $(0.8 \%)$ stained with ethidium bromide, with standard DNA from bacteriophage Lambda (Fer-

TABLE 1. Mean deoxynivalenol (DON) and DON-3-glucoside (D3G) content in different parts of winter wheat 'Ritmo' and 'Toras' plants inoculated in the seedling stage with a spore suspension of Fusarium culmorum $^{\mathrm{z}}$

\begin{tabular}{lccccc}
\hline & \multicolumn{4}{c}{ Content $\left(\mu \mathrm{g} \mathrm{kg}^{-1}\right.$ dry weight $)$} \\
\cline { 2 - 3 } \cline { 5 - 6 } Treatment, organ & Ritmo & Toras & & \multicolumn{2}{c}{ Ritmo } \\
\cline { 2 - 3 } \cline { 5 - 6 } F. culmorum & & & & Toras \\
Stem base & $8,716.67 \mathrm{a}$ & $17,140.00 \mathrm{a}$ & & $3,800.00 \mathrm{ab}$ & $8,220.00 \mathrm{a}$ \\
Ear rachis & $750.00 \mathrm{bc}$ & $1,960.00 \mathrm{~b}$ & & $333.00 \mathrm{~cd}$ & $440.00 \mathrm{~cd}$ \\
Husk & $550.00 \mathrm{bc}$ & $1,120.00 \mathrm{~cd}$ & & $686.00 \mathrm{bc}$ & $200.00 \mathrm{~cd}$ \\
Grain & $0.00 \mathrm{~d}$ & $0.00 \mathrm{~d}$ & & $0.00 \mathrm{~d}$ & $0.00 \mathrm{~d}$ \\
Control & & & & & \\
Stem base & $0.49 \mathrm{~cd}$ & $0.00 \mathrm{~d}$ & & $0.00 \mathrm{~d}$ & $0.00 \mathrm{~d}$ \\
Ear rachis & $0.00 \mathrm{~d}$ & $0.00 \mathrm{~d}$ & & $0.00 \mathrm{~d}$ & $0.00 \mathrm{~d}$ \\
Husk & $0.00 \mathrm{~d}$ & $0.00 \mathrm{~d}$ & & $0.00 \mathrm{~d}$ & $0.00 \mathrm{~d}$ \\
Grain & $0.00 \mathrm{~d}$ & $0.00 \mathrm{~d}$ & & $0.00 \mathrm{~d}$ & $0.00 \mathrm{~d}$ \\
\hline
\end{tabular}

${ }^{\mathrm{z}}$ Each analytical sample consisted of the identical plant parts merged from six plants ( $n=6$ for Ritmo and $n=5$ for Toras). DON and D3G levels followed by the same letter are not significant different according to Fisher's least significant difference test $(P \leq 0.05)$. Data were $\log$-transformed $(\log (x+1))$ prior to analysis of variance. mentas, St. Leon-Rot, Germany). Fungal biomass in plant tissue was quantified by determination of fungal DNA with speciesspecific qPCR. For amplification and melting curve analysis, the iCycler system from Bio-Rad was used. PCR quantification of F. culmorum DNA was conducted as described previously (5), with few modifications. Quantification took place in $25 \mu \mathrm{l}$ of reaction mix, containing $12.5 \mu \mathrm{l}$ of Premix Absolute Blue qPCR SYBR green fluorescein (Thermo Fisher Scientific), with an adapted annealing temperature of $67^{\circ} \mathrm{C}$.

The amount of fungal DNA was determined from calibration curves obtained with fungal DNA at 0.5 to $500 \mathrm{pg}$ dissolved in the respective plant DNA matrix. Samples with cycle threshold values higher than the value of $0.5 \mathrm{pg}$ of standard DNA were regarded as free from fungal colonization.

Statistical analysis. Statistical analysis was performed with the computer software Statistica (StatSoft, Tulsa, USA). Two different statistical tests were applied. Readings from disease severity scoring at the stem base were ordinally scaled and assigned to severity categories from zero to three. Therefore, the univariate nonparametric Kruskal-Wallis test was applied. Readings from DON and D3G were $\log$-transformed with the formula $\log (x+1)$ prior to analysis of variance to obtain a suitable distribution of the residuals. Log-transformed data and fungal biomass quantification data were analyzed for significant differences with the least significant difference post-hoc test.

\section{RESULTS}

Systemic translocation of DON and D3G in wheat plants infected with $\boldsymbol{F}$. culmorum at the stem base. Symptoms of seedling infection were detectable 5 days postinoculation. Some weaker plants died through seedling blight, which indicated a strong infection, but most plants readily developed into mature plants. In GS $77, \approx 77 \%$ of the Toras plants and $82 \%$ of the Ritmo plants inoculated with $F$. culmorum had slight to severe crown rot symptoms at the stem base. Mean values of disease scores for plants infected with $F$. culmorum were significantly higher $(P \leq$ $0.01)$ than values from noninoculated controls. Disease severity of FCR on Ritmo (1.11) and Toras (0.90) did not differ significantly. The plants were watered from the bottom in order to avoid any wetness on the soil or plant surface. Together with strict avoidance of air streams, these measures prevented any secondary fungal infection of green plant parts.

Elevated to high concentrations of DON were detected at GS 92 in all plant parts except for the grains. Stem base samples of both cultivars showed the highest DON content compared with the other organs (Table 1). The levels of DON in the stem base were 800 to $38,700 \mu \mathrm{g} \mathrm{kg}^{-1}$ dry weight (DW) in Toras and 900 to $32,200 \mu \mathrm{g} \mathrm{kg}^{-1} \mathrm{DW}$ in Ritmo, with no significant differences between cultivars. The amount of DON detected in one noninoculated plant indicated a low background contamination with $F$. culmorum in the soil. The analysis of symptomless ears of Ritmo and Toras showed elevated DON levels in the husks (0 to 2,400 $\mu \mathrm{g}$ DON kg${ }^{-1}$ DW in Ritmo and 0 to $5,600 \mu \mathrm{g} \mathrm{kg}^{-1} \mathrm{DW}$ in Toras) and high levels in the ear rachis (200 to $4,000 \mu \mathrm{g} \mathrm{kg}^{-1} \mathrm{DW}$ in Ritmo and 200 to $8,800 \mu \mathrm{g} \mathrm{kg}{ }^{-1}$ DW in Toras) of inoculated plants. After stem base infection, the highest quantities of DON in upper plant parts were found in the ear rachis of Toras and Ritmo $\left(\leq 8,800 \mu \mathrm{g} \mathrm{kg}^{-1} \mathrm{DW}\right.$ in Toras and 4,000 $\mathrm{g} \mathrm{kg} \mathrm{k}^{-1} \mathrm{DW}$ in Ritmo), which significantly exceeded the contamination with DON in the husks and grain of Toras and the grains of Ritmo. In Ritmo, DON levels of the ear rachis and husks were similar but significantly higher than in grains (Table 1). Grain samples of inoculated plants consistently lacked any detectable level of DON (Fig. 1). Whenever plant tissue from upper plant parts of noninoculated or inoculated plants was analyzed, it was free of fungal DNA. Similarly, DON was consistently absent in upper parts of noninoculated plants. 
An important aspect of this study was to investigate whether glycosylation of DON, as reported from infected ears, also occurs in the stem base with FCR. The levels of DON glucoside were elevated in the stem base for both Ritmo and Toras, with D3G at 0 to $8,200 \mu \mathrm{g} \mathrm{kg}^{-1} \mathrm{DW}$ in Ritmo and 0 to $19,300 \mu \mathrm{g} \mathrm{kg}^{-1} \mathrm{DW}$ in Toras. These amounts were significantly higher than in all other organs being analyzed (Table 1). This result indicates that the conversion of DON to D3G predominantly took place in the infected tissue. However, a significant amount of D3G was also detectable in the upper plant parts, indicating its systemic mobility similar to DON. In Ritmo, the highest quantities were found in the husks (D3G at $\leq 2,100 \mu \mathrm{g} \mathrm{kg}^{-1} \mathrm{DW}$ ) whereas, in Toras, the highest levels were detected in the ear rachis (D3G at $\leq 2,200 \mu \mathrm{g}$ $\mathrm{kg}^{-1} \mathrm{DW}$ ). The ratio between D3G and DON in the husk was $\approx 1.5$ and 1.3 in the ear rachis.

The movement of DON in the rachis was followed with fluorescence microscopy. After capillary uptake, fluorescein-labeled DON was visible in the xylem vessels of the rachis (Fig. 2B and C). Sections from control plants showed no fluorescence in xylem vessels (Fig. 2A). Examination of semithin sections from the rachis-seed interface showed a layer of thick-walled cells in the rachilla, interrupting the vascular connection and, thereby, presumably providing a morphological barrier to the free movement of DON-fluorescein to the filling grain (Fig. 2D to F). As a result, there was no DON-fluorescein detectable in tissue and filling grains beyond this anatomical interface zone.
In order to verify the hypothesis that elevated toxin concentrations in upper plant parts originated from systemic translocation of toxins produced in infected stem base tissue, the systemic growth of the fungal pathogen was followed by qPCR in all plant parts sampled for DON analyses. Fungal DNA was only detectable in the stem base (Table 2), with levels significantly higher in Toras $\left(1,706 \mathrm{pg} \mathrm{mg}^{-1} \mathrm{DW}\right)$ than in Ritmo $\left(1,146 \mathrm{pg} \mathrm{mg}^{-1} \mathrm{DW}\right)$. In accordance with low amounts of DON detected in noninoculated Ritmo plants, low levels of $F$. culmorum DNA were detected in some noninoculated plants, indicating a slight stem base infection from fungal inoculum in the soil substrate.

DON detoxification in different plant parts. D3G was present in significant amounts in the stem base, ear rachis, and husks; however, not in grains. The levels of D3G in the stem base of Toras significantly exceeded those in any other plant organ (Table 1). Transcript levels of the genes UGT and CYP450 determined in GS 77 were significantly increased in the stem base of each cultivar (Fig. 3A and B). The resistant Toras also showed a higher accumulation of CYP450 transcripts in the stem base compared with the FHB-susceptible Ritmo whereas, in the other organs, no differences were found. Transcript levels for CYP450 were consistently elevated in the stem base of both cultivars and significantly higher than in upper plant parts. The lowest level of transcripts was found in the filling grains. Expression of UGT was higher in all organs of Ritmo than in Toras, which was a significant effect in the ear rachis.

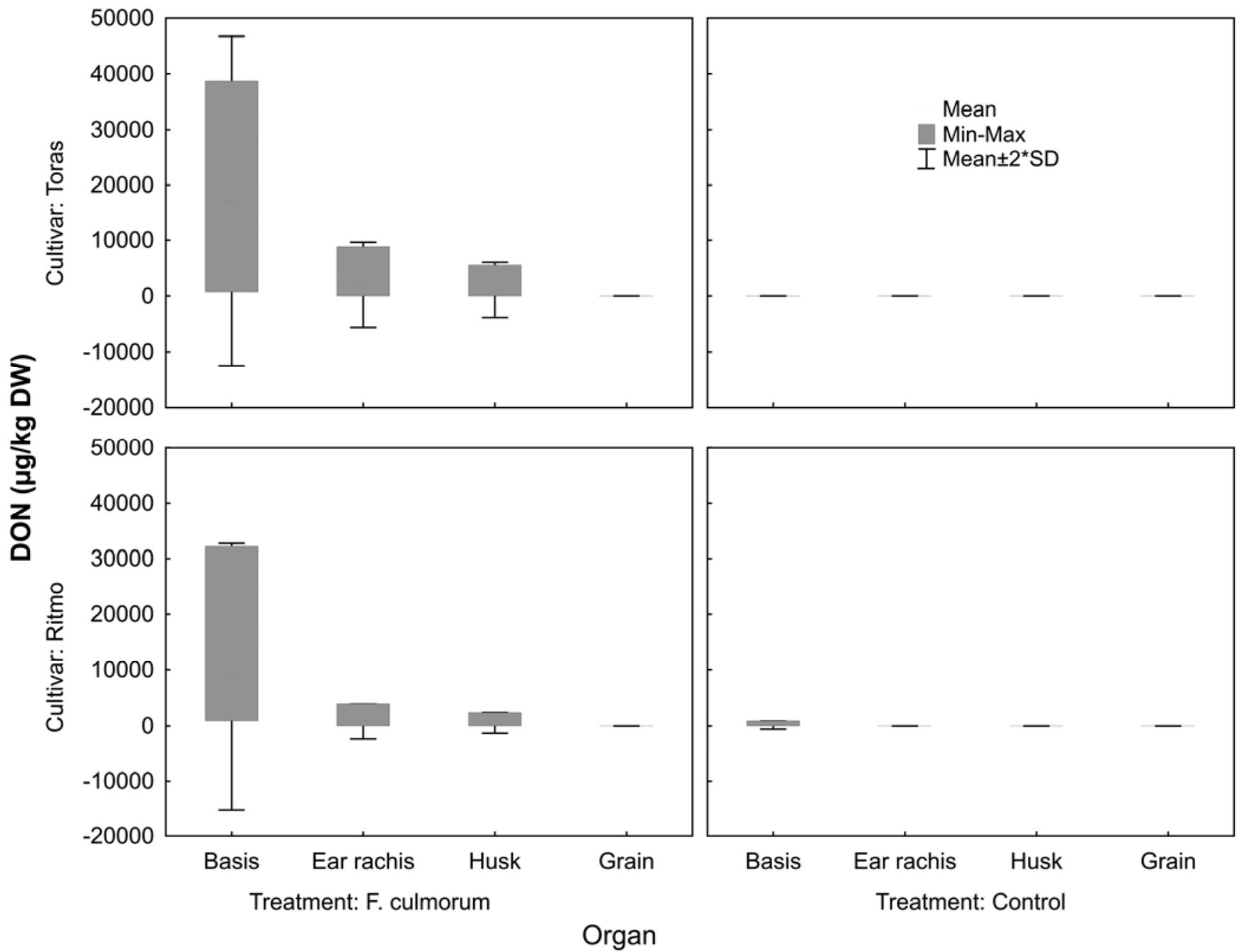

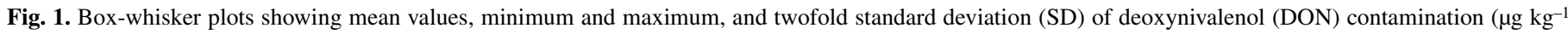

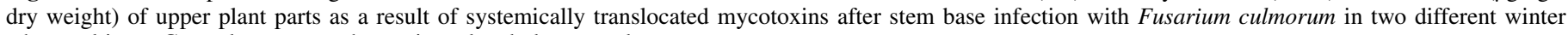
wheat cultivars. Control represents the noninoculated plant samples. 


\section{DISCUSSION}

This study reports on the systemic translocation of a key $F u$ sarium mycotoxin, DON, its detoxification in different plant tissues, and the inhibition of mycotoxin transfer into the grains in two wheat cultivars after stem base infection with F. culmorum.

Disease severity of Toras and Ritmo after dip inoculation was similar but fungal DNA levels in the stem base were higher in the FHB-resistant Toras, which is in agreement with a previous report on lack of correlation between resistance to infection of ears and stem bases (20).
Contamination of symptomless wheat ears with DON has been reported from northern Germany (31) but its causal relationships were unclear. Furthermore, plants from microplot experiments (data not shown) showed DON contamination but no presence of $F$. culmorum or $F$. graminearum DNA in a number of samples from upper plant parts. Surprisingly, grains from such plants contained extremely low levels of DON. Analysis with qPCR revealed that $F$. culmorum was the prevailing pathogen in the stem bases of such plants. This is in accordance with earlier studies, in which wheat stem bases have been analyzed with species-specific qPCR (2). F. culmorum is known to be a relatively strong com-

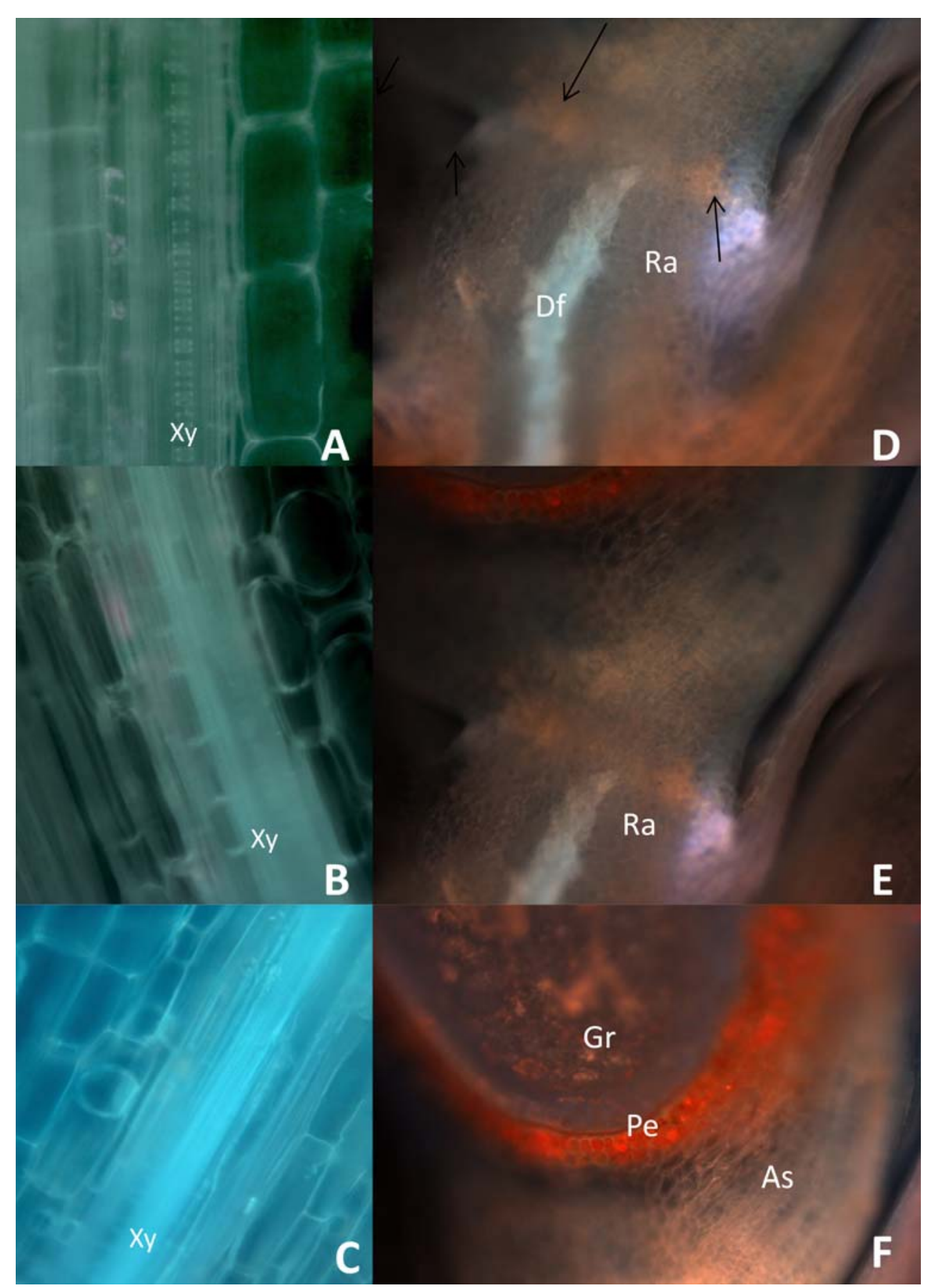

Fig. 2. Fluorescence microscopic localization of deoxynivalenol (DON)-fluorescein in semithin sections from the wheat spikelet of wheat plants ('Toras'). Fluorescein-labeled DON was applied by natural capillary uptake of the vascular system from a DON-fluorescein source. A, Untreated control, xylem vessel (Xy) of rachis is free of DON-fluorescein. B and C, DON-fluorescein in xylem vessels of the rachis after capillary uptake. DON-fluorescein showed strong signal in xylem vessels. D to F, Series of pictures of a longitudinal section from the rachis-seed interface. D, DON-fluorescein (Df) passes from the rachis through the rachilla $(\mathrm{Ra})$ toward the filling grain. Movement is discontinued by a barrier of thick-walled cells (arrows). E, Larger view of the rachilla-seed interface tissue, including rachillary xylem, discontinuity zone, and base of the maturing grain. F, At the wheat grain attachment site (As) and in the pericarp (Pe) and lower part of the filling grain $(\mathrm{Gr})$, no DON-fluorescein is detectable due to effective blocking of the DON-fluorescein transport in the rachilla. 
petitor in colonizing the soil. In contrast to $F$. graminearum, $F$. culmorum can survive with chlamydospores for at least 3 years (16). Therefore, F. culmorum was chosen for experiments under controlled conditions in this study.

The striking observation was the detection of DON in all plant parts, except for the grains. Although no fungal DNA was present in the upper parts of the plants, DON and D3G accumulated in the rachis and husks but did not contaminate maturing grains (Fig. 1). There are few earlier reports indicating that DON is able to move away from the initial site of infection (38) or may occur in noninfested plant tissue (18). The fact that DON is water soluble and produced in the stem bases in quantities as large as in infected ears (25; this study) implies the potential of an upward transport in the aqueous phase via the transpiration stream in the xylem vessels over a long distance. This is possibly enabled by the colonization of the whole basal wheat culm, including the xylem vessels by $F$. culmorum (6). In an immunocytochemical study, the presence of DON in tracheary elements of the rachis after ear infection was demonstrated and a possible transport of the toxin with the xylem sap anticipated (17). Using DON labeled with a fluorescent dye, we proved that DON can be transported within xylem vessels of the rachis, corroborating the view that the main path of translocation of DON from lower plant parts into the ears is via xylem elements. This is in contrast to the transport through the phloem within heads during FHB infection, as suggested by Snijders and Krechting (33).

The present study showed that significant amounts of DON produced in the stem base are transformed into D3G. D3G was also found in significant amounts in upper plant parts. This could be due to either similar systemic translocation as seen with DON or due to DON being converted into D3G after translocation to upper plant parts. Interestingly, the conversion of DON into D3G in the stem base was higher in Toras, though Toras was more susceptible to FCR than Ritmo. Thus, this type of resistance to Fusarium, denoted as type V resistance (24), apparently does not play a substantial role during FCR infection of the two cultivars. This is in contrast to studies on factors of FHB resistance of wheat ears, among which a major FHB resistance locus (3BS, derived from Sumai 3) has been identified, which is considered responsible for D3G formation (19). Although the detoxification of DON had no significant impact on stem base resistance during this study, it was recently shown that the presence or absence of DON is responsible for the virulence of F. culmorum during FCR of durum wheat (30).

Li et al. (21) showed that the CYP450 gene was induced during infection of ears and seedlings with Fusarium spp. The authors concluded that a differential expression of the observed CYP450 gene was triggered by DON in a resistance-dependent way. Walter et al. (36) reported that the genes CYP450 and UGT were induced after DON treatment of the spikelet. In both cultivars, the genes for CYP450 and UGT were considered to play a role in the host defense response to F. culmorum and its mycotoxin DON, respectively, because they displayed the highest levels of transcript accumulation in the stem base compared with any of the other plant organs analyzed. In general, certain CYP450 and glycosyltransferases genes are known to be involved in the natural detoxification of xenobiotics in plants (7). CYP450 genes often activate xenobiotics prior to glycosylation but the role of the observed CYP450 gene in DON detoxification and plant response to $F$. culmorum infection is unclear. During DON detoxification, UGTs attach glucose to the hydroxyl group at the C3 position. Numerous UGTs are known and one recent study provided the first evidence for their potential involvement in DON glycosylation. In this study, Schweiger et al. (32) demonstrated glycosylation of DON by heterologous expression of a barley UGT gene (HvUGT13248) in yeast. The primers used in our study amplified one of the wheat homologues. The deduced amino acid sequence of that gene showed $95 \%$ similarity to that of the barley gene. Therefore, we assume that the product of the gene is involved in DON glycosylation and that the DON detoxification predominantly took place in the infected tissue where DON was produced.

There are several studies indicating a translocation of DON following stem base infection with Fusarium spp. (10,25). Here, we report on the differential contamination of upper plant parts like husks, ear rachis, and grains following stem infection with DON-producing isolates of $F$. culmorum. The comparison of DON levels in these tissues revealed that grains are protected against the systemic influx of DON. This result is in line with a previous report that DON was found in the rachis at twice the concentration found in spikelets after a central spikelet has been inoculated (29). Similarly, Covarelli et al. (10) found a 15.4-fold higher level of DON in the rachis than in mature grains after DON was translocated from the infected stem base to the head. This prompted the assumption that a physical or physiological barrier may prevent DON transport into the grain.

One possible explanation for the sharp differences in DON levels found in rachis and grains at mature growth stages (GS 92) was local plant-derived DON glycosylation, as previously described for wheat $(4,19)$. Conversion of DON to DON glucosides is considered an important resistance component mitigating DON contamination of the ear. However, D3G analysis in this study clearly showed that DON glycosylation was not the key factor in protecting grains from accumulation with harmful fungal metabolites. This result was supported by the expression analysis of a gene putatively involved in DON glycosylation. Some earlier studies have reported on the inhibition of DON movement within the wheat ear during FHB disease. It has been hypothesized that a membrane-based trichothecene barrier inhibits or limits DON transfer from the chaff to the kernel (33). Here, we provide evidence for a mechanism controlling mycotoxin influx into the grain. This new view is derived from a histological finding of interruption of vascular transport by "xylem discontinuity" in the rachilla-seed interspace. The general route for carbohydrate-rich assimilates from the photosynthetic site of production into the filling grain are the sieve elements of the phloem, whereas water and minerals are streaming through the xylem vessels. Fluorescence microscopic studies with fluorescein-labeled DON suggested the translocation of mycotoxins with the transpiration stream through the xylem bundles. A crucial region for the vascular bundles directing toward the caryopsis of wheat is the upper rachilla, connecting grains and rachis. A special anatomical feature of the xylem vessels consists of a core zone of tissue bearing thick-walled cells, known as xylem discontinuity (39), which disrupts the direct continuation of tracheary elements between the rachilla and the seed pericarp. With the aid of fluorescence micro-

TABLE 2. Mean content of fungal DNA in different tissues of winter wheat 'Ritmo' and 'Toras' plants inoculated in the seedling stage with a spore suspension of Fusarium culmorum ${ }^{\mathrm{z}}$

\begin{tabular}{lrr}
\hline & \multicolumn{2}{c}{ DNA content $\left(\mathrm{pg} \mathrm{mg}^{-1}\right.$ dry weight $)$} \\
\cline { 2 - 3 } Treatment, organ & \multicolumn{1}{c}{ Ritmo } & Toras \\
\hline F. culmorum & & \\
Stem base & $146.06 \mathrm{~b}$ & $1,706.37 \mathrm{a}$ \\
Ear rachis & $0.00 \mathrm{~d}$ & $0.00 \mathrm{~d}$ \\
Husk & $0.00 \mathrm{~d}$ & $0.00 \mathrm{~d}$ \\
Grain & $0.00 \mathrm{~d}$ & $0.00 \mathrm{~d}$ \\
Control & & \\
Stem base & $69.67 \mathrm{c}$ & $0.00 \mathrm{~d}$ \\
Ear rachis & $0.00 \mathrm{~d}$ & $0.00 \mathrm{~d}$ \\
Husk & $0.00 \mathrm{~d}$ & $0.00 \mathrm{~d}$ \\
Grain & $0.00 \mathrm{~d}$ & $0.00 \mathrm{~d}$ \\
\hline
\end{tabular}

${ }^{\mathrm{z}}$ Each analytical sample consisted of the identical plant parts merged from six plants ( $n=6$ for Ritmo and $n=5$ for Toras). Means followed by different letters significantly differ at $P \leq 0.05$ according to the least significant difference test. 
scopy (Fig. 2), we identified the xylem discontinuity and showed that DON labeled with fluorescence dye neither crossed this histological barrier nor accumulated beyond this zone in the seed pericarp or grain. This histological finding is in full agreement with the bioanalytical data on the distribution of DON in different plant tissues (see above).

Earlier studies have demonstrated that xenobiotics such as fluorochromes and acid fuchsin, transported with the transpiration stream in xylem vessels, were not able to cross the xylem discontinuity $(8,28,39)$. Furthermore, Frick and Pizzolato (13), in a study with Anthoxanthum spp., revealed that the anatomical specialization of tracheary elements forces the water flux away from the caryopsis. Together with the findings of this study, these results provide strong evidence that the xylem discontinuity of tracheary elements in the interface between rachilla and seed pericarp is an efficient barrier for xenobiotics such as fungal
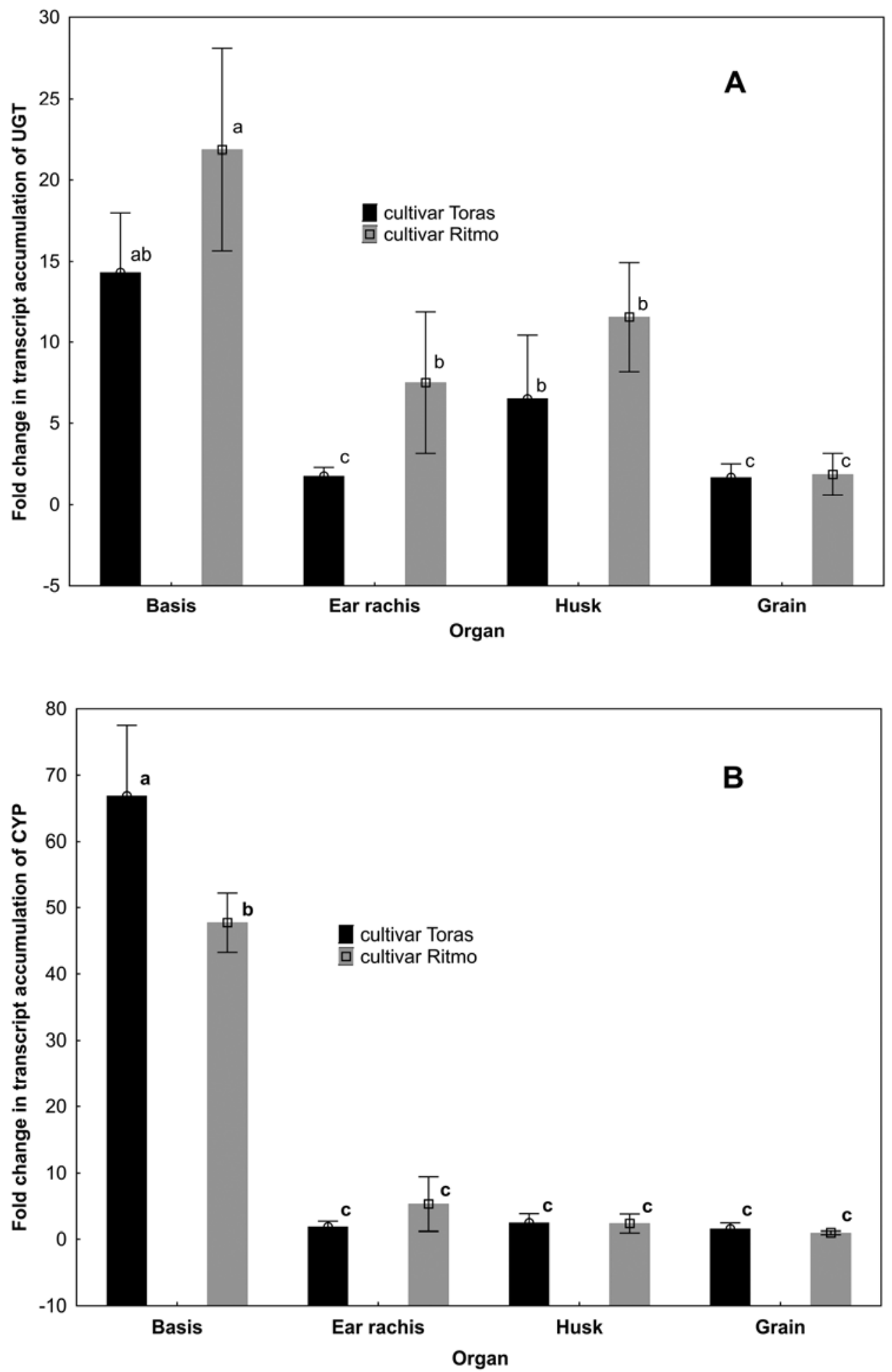

Fig. 3. Accumulation of transcript homologues to A, Uridine diphosphate-glycosyltransferase (UGT) and B, cytochrome P450 (CYP450) in response to stem base infection with a deoxynivalenol (DON)-producing strain of Fusarium culmorum. Fold changes of DON-responsive genes are analyzed in four wheat plant organs (stem basis, ear rachis, husk, and grain) in growth stage 77. The two wheat cultivars analyzed strongly differ in resistance to Fusarium head blight ('Toras' = resistant and 'Ritmo' = susceptible). Extension bars represent \pm one standard error of the mean. Different lowercase letters indicate significant differences between fold change means according to Kruskal-Wallis test $(P \leq 0.05)$. 
toxins translocated from distant infection sites with the xylem sap. This mechanism appears to act independently from cultivar resistance to FHB and has the potential to significantly mitigate additional risks of grain contamination from basal $F$. culmorum infections. Control of DON levels in grains do not appear to be due to enhanced detoxification in this plant tissue. In conclusion, stem base infection of wheat with $F$. culmorum may represent an additional source of mycotoxins in ears but there exists a morphological barrier consisting of thick-walled cells at the ear-seed interface which effectively controls the uptake of plant basederived mycotoxins into the grains.

\section{ACKNOWLEDGMENTS}

We thank the Agency for Renewable Resources (FNR) for funding this research and C. Nordmann for great technical assistance.

\section{LITERATURE CITED}

1. Adejumo, T. O., Hettwer, U., and Karlovsky, P. 2007. Occurrence of Fusarium species and tricothecenes in Nigerian maize. Int. J. Food Microbiol. 116:350-357.

2. Bateman, G. L., Gutteridge, R. J., Gherbawy, Y., Thomsett, M. A., and Nicholson, P. 2007. Infection of stem bases and grains of winter wheat by Fusarium culmorum and F. graminearum and effects of tillage method and maize-stalk residues. Plant Pathol. 56:604-615.

3. Beccari, G., Covarelli, L., and Nicholson, P. 2011. Infection processes and soft wheat response to root rot and crown rot caused by Fusarium culmorum. Plant Pathol. 60:671-684.

4. Berthiller, F., Dall'Asta, C., Schuhmacher, R., Lemmens, M., Adam, G., and Krska, R. 2005. Masked mycotoxins: determination of a deoxynivalenol glucoside in artificially and naturally contaminated wheat by liquid chromatography-tandem mass spectrometry. J. Agric. Food Chem. 53:3421-3425

5. Brandfass, C., and Karlovsky, P. 2008. Upscaled CTAB-based DNA extraction and real-time PCR assays for Fusarium culmorum and $F$. graminearum DNA in plant material with reduced sampling error. Int. J. Mol. Sci. 9:2306-2321.

6. Clement, J., and Parry, D. 1998. Stem-base disease and fungal colonization of winter wheat grown in compost inoculated with Fusarium culmorum, F. graminearum and Microdochium nivale. Eur. J. Plant Pathol. 104:323-330.

7. Coleman, J., Blake-Kalff, M., and Davies, T. G. E. 1997. Detoxification of xenobiotics by plants: chemical modification and vacuolar compartmentation. Trends Plant Sci. 2:144-151.

8. Cook, H., and Oparka, K. J., 1983. Movement of fluorescein into isolated caryopses of wheat and barley. Plant Cell Environ. 6:239-242

9. Cook, R. J. 1968. Fusarium root and foot rot of cereals in the Pacific Northwest. Phytopathology 58:127-131.

10. Covarelli, L., Beccari, G., Steed, A., and Nicholson, P. 2012. Colonization of soft wheat following infection of the stem base by Fusarium culmorum and translocation of deoxynivalenol to the head. Plant Pathol. doi: 10.1111/j.1365-3059.2012.02600.x

11. Duthie, J., and Hall, R. 1987. Transmission of Fusarium graminearum from seed to stems of winter wheat. Plant Pathol. 36:33-37.

12. European Commission. 2005. Commission regulation (EC) no. 856/2005 of 6 June 2005 amending regulation (EC) no. 466/2001 as regards Fusarium toxins. Off. J. Eur. Union L 143/3-8.

13. Frick, H., and Pizzolato, T. D., 1987. Adaptive value of the xylem discontinuity in portioning of photoassimilate to grain. B. Torrey Bot. Club $114: 252-259$

14. Goswami, R. S., and Kistler, H. C. 2004. Heading for disaster: Fusarium graminearum on cereal crops. Mol. Plant Pathol. 5:515-525.

15. Halterman, D. A. 2003. Powdery mildew-induced Mla mRNAs are alternatively spliced and contain multiple upstream open reading frames. Plant Physiol. 131:558-567.

16. Inglis, D., and Cook, R. J. 1986. Persistence of chlamydospores of Fusarium culmorum in wheat field soils of eastern Washington. Phytopathology 76:1205-1208.

17. Kang, Z., and Buchenauer, H. 1999. Immunocytochemical localization of Fusarium toxins in infected wheat spikes by Fusarium culmorum. Physiol. Mol. Plant P. 55:275-288.

18. Kang, Z., and Buchenauer, H. 2002. Studies on the infection process of
Fusarium culmorum in wheat spikes: Degradation of host cell wall components and localization of trichothecene toxins in infected tissue. Eur. J. Plant Pathol. 108:653-660.

19. Lemmens, M., Scholz, U., Berthiller, F., Dall'Asta, C., Koutnik, A., Schuhmacher, R., Adam, G., Burstmayr, H., Mesterházy, A., Krska, R., and Ruckenbauer, P. 2005. The ability to detoxify the mycotoxin deoxynivalenol colocalizes with a major quantitative trait locus for Fusarium head blight resistance in wheat. Mol. Plant-Microbe Interact. 18:13181324.

20. Li, H. B., Xie, G. Q., Ma, J., Liu, G. R., Wen, S. M., Ban, T., Chakraborty, S., and Chun, J. L. 2010. Genetic relationships between resistances to Fusarium head blight and crown rot in bread wheat (Triticum aestivum L.). Theor. Appl. Genet. 121:941-950.

21. Li, X., Zhang, B., Li, H. P., Xu, H. Q., Qu, B., Dang, F. J., and Liao, Y. C. 2010. Resistance to Fusarium head blight and seedling blight in wheat is associated with activation of a cytochrome P450 gene. Phytopathology 100:183-191.

22. Livak, K. J., and Schmittgen, T. D. 2001. Analysis of relative gene expression data using real-time quantitative PCR and the $2-\Delta \Delta C T$ method. Methods 25:402-408.

23. Mentewab, A. 2000. Chromosomal location of Fusarium head blight resistance genes and analysis of the relationship between resistance to head blight and brown foot rot. Plant Breed. 119:15-20.

24. Mesterházy, Á. 2002. Role of deoxynivalenol in aggressiveness of $F u$ sarium graminearum and $F$. culmorum and in resistance to Fusarium head blight. Eur. J. Plant Pathol. 108:675-684.

25. Mudge, A., Dill-Macky, R., Dong, Y., Gardiner, D., White, R., and Manners, J. 2006. A role for the mycotoxin deoxynivalenol in stem colonization during crown rot disease of wheat caused by Fusarium graminearum and Fusarium pseudograminearum. Physiol. Mol. Plant Pathol. 69:73-80.

26. Parry, D. W., Jenkinson, P., and McLeod, L. 1995. Fusarium ear blight (scab) in small grain cereals-A review. Plant Pathol. 44:207-238.

27. Placinta, C. M., D'Mello, J. B. F., and MacDonald, A. M. C. 1999. A review of world contamination of cereal grains and animal feed with Fusarium mycotoxins. Anim. Feed Sci. Technol. 78:21-37.

28. Sakri, F. A. K., and Shannon, J. C. 1975. Movement of ${ }^{14}$ C-labelled sugars into kernels of wheat (Triticum aestivum L.). Plant Physiol. 55:881-889.

29. Savard, M. E., Ramesh, S. C., Seaman, L. W., and Fedak, G. 2000. Sequential distribution of the mycotoxin deoxynivalenol in wheat spikes after inoculation with Fusarium graminearum. Can. J. Plant Pathol. 22:280-285.

30. Scherm, B., Orrù, M., Balmas, V., Spanu, F., Azara, E., Delugo, G., Hammond, T. M., Keller, N. P., and Migheli, Q. 2011. Altered trichothecene biosynthesis in TRI6-silenced transformants of Fusarium culmorum influences the severity of crown and foot rot on durum wheat seedlings. Mol. Plant Pathol. 12:759-771.

31. Schlüter, K., Kropf, U., and Karlovsky, P. 2006. Untersuchungen zur systemischen Infektion von Fusarium culmorum an Winterweizen in Schleswig-Holstein. Gesunde Pflanz. 58:107-116.

32. Schweiger, W., Boddu, J., Shin, S., Poppenberger, B., Berthiller, F., Lemmens, M., Muehlbauer, G., and Adam G. 2010. Validation of a candidate Deoxynivalenol-inactivating UDP-glucosyltransferase from barley by heterologous expression in yeast. Mol. Plant-Microbe Interact. 23:977986.

33. Snijders, C. H. A., and Krechting, C. F. 1992. Inhibition of deoxynivalenol translocation and fungal colonization in Fusarium head blight resistant wheat. Can. J. Bot. 70:1570-1576.

34. Tottman, D. R. 1987. The decimal code for the growth stages of cereals, with illustrations. Ann. Appl. Biol. 110:441-454.

35. Venkatesh, B., Hettwer, U., Koopmann, B., and Karlovsky, P. 2005. Conversion of cDNA differential display results (DDRT-PCR) into quantitative transcription profiles. BMC Genomics 6:51.

36. Walter, S., Brennan, J. M., Arunachalam, C., Ansari, K. I., Hu, X., Khan, M. R., Trognitz, F., Trognitz, B., Leonard, G., Egan, D., and Doohan, F. 2008. Components of the gene network associated with genotype-dependent response of wheat to the Fusarium mycotoxin deoxynivalenol. Funct. Integr. Genomic 8:421-427.

37. Wiese, M. V. 1987. Compendium of Wheat Diseases, 2nd ed. American Phytopathological Society Press, St. Paul, MN.

38. Young, J., and Miller, J. 1985. Appearance of fungus, ergosterol and $F u$ sarium mycotoxins in the husk, axial stem and stalk after ear inoculation of field corn. Can. J. Plant Sci. 65:47-53.

39. Zee, S. Y., and O'Brien, T. P. 1970. A special type of tracheary element associated with "xylem discontinuity" in the floral axis of wheat. Aust. J. Biol. Sci. 23:783-791. 